\title{
Article \\ Symbols of the New Districts in Ukraine: Chervonohrad Raion as an Example
}

\author{
Andriy Grechylo $\mathbb{1 0}$
}

check for

updates

Citation: Grechylo, Andriy. 2022

Symbols of the New Districts in

Ukraine: Chervonohrad Raion as an Example. Genealogy 6: 6. https:// doi.org/10.3390/genealogy6010006

Received: 5 December 2021

Accepted: 28 December 2021

Published: 7 January 2022

Publisher's Note: MDPI stays neutral with regard to jurisdictional claims in published maps and institutional affiliations.

Copyright: (C) 2022 by the author. Licensee MDPI, Basel, Switzerland. This article is an open access article distributed under the terms and conditions of the Creative Commons Attribution (CC BY) license (https:// creativecommons.org/licenses/by/ $4.0 /)$.
M.S. Hrushevsky Institute of Ukrainian Archeography and Source Studies, National Academy of Sciences of Ukraine, 03142 Kyiv, Ukraine; grechylo@yahoo.com; Tel.: +380-50-665-4583

\begin{abstract}
The article examines the beginning of the creation of symbols for the new raions (districts) In 2020, Ukraine underwent an administrative reform to merge most of the existing 490 districts, resulting in the creation of 136 new raions. We have proposed three options for solving the problems with the coats of arms and flags of the new districts. The practical implementation of these methodological developments is considered in the example of the Chervonohrad raion (the Lviv region). The symbols of this district were developed and approved in the summer of 2021. They managed to combine the symbols of the ancient historical land, and the current administrative center, and the old districts.
\end{abstract}

Keywords: heraldry in Ukraine; Chervonohrad raion; coat-of-arms; flag

\section{Introduction}

Since 1990, the Ukrainian Heraldry Society has actively conducted research in heraldry and vexillology. In a relatively short span of time, a great deal of work has been conducted in archives, a lot of heretofore unknown materials have been discovered, and Ukrainian and foreign heraldry (mainly that of neighboring countries) has been studied. On this basis, the main principles and rules of modern Ukrainian municipal heraldry and vexillology have been developed. Wide-ranging discussions on these issues were held at annual heraldic conferences and, as a result, the methodology and basic principles of modern heraldic art have been elaborated. The results of theoretical studies are being implemented gradually by providing free consultations to local authorities, expert evaluations, or preparing designs to order. Through the efforts of society members, it was possible to both renew old symbols and create new emblems and flags for more than 2000 cities, towns, villages, districts, and regions in Ukraine. Obviously, only a scholarly approach and the organization of existing symbols in accordance with heraldic norms in addition to new heraldic designs will enable the creation of a science firmly based on a system of municipal and territorial heraldry and vexillology. Unfortunately, there is still no state authority in Ukraine that would coordinate local symbols. The Ukrainian Heraldry Society coordinates work in these fields and regularly provides assistance to local authorities.

\section{Administrative Reform}

Ukraine is a unitary state. According to the Article 133 of Constitution of Ukraine, "the system of the administrative and territorial structure of Ukraine is composed of the Autonomous Republic of Crimea, oblasts, raions, cities, districts in city, settlements, and villages". Therefore, the top level of the administrative division in Ukraine is made up of oblasts (regions or provinces). Raions (districts) are the second level.

Rural raions did not have their own coats of arms in the Soviet Union. A new law on local self-government was adopted in Independent Ukraine in 1997. It gave the right not only to cities and towns to adopt and own their own symbols but also to oblasts, raions, and villages. Unfortunately, no separate law on local heraldry has been passed. From the 
end of the 1990s to 2020, 480 raions approved their symbols (Символіка 2001, 2004, 2005; Терлецький and Гречило 2006; Кривенко and Шляховий 2008; Кисляк 2020). Most of these projects were developed in collaboration with the Ukrainian Heraldry Society.

On 17 July 2020, the Verkhovna Rada (Parliament of Ukraine) approved the administrative reform to merge most of the existing 490 raions, resulting in the creation of 136 new raions ${ }^{1}$. New districts were formed by merging several old districts. Formally, this did not mean that it was necessary to develop new symbols for all new raions. However, it is necessary to approach each raion individually in every case.

In the past, we developed guidelines for creating a heraldic system of coats of arms of cities, towns, villages, rural districts, and regions (Гречило 2001). In 2020, we proposed three possible solutions to the problems with the symbols of the new raions (Гречило 2020a).

The first option is to preserve the old symbols of the district which has now been enlarged. This is possible if its old coats of arms and flags in content fully emphasize the identity and features of the new raion. This approach will also save money, as most of these symbols are already made and used in administrative buildings, interior decoration, offices, etc. For example, the old symbols of Sambir, Stryi, and Drohobych districts also characterize well the features of the new raions.

The second option is to create new symbols with a combination of coats of arms (or their individual elements) of the old districts. This will lead to the appearance of either complex coats of arms or composed of more details. A similar approach is provided for the development of the flags of new districts. This solution is good for those cases where there is some competition between the "old" raions, because in this case, they will all be reflected in the new symbols. An example is the new Zolochiv raion, formed of three old districts (Zolochiv, Brody, and Busk), each competed for the right to be the administrative center and wanted to emphasize their features.

The third option is to create completely new coats of arms and flags (possibly with the use of some successful charges from the old symbols). This approach is good when the coats of arms or flags of the old districts have failed, and it is difficult to use something for the new (as an example: Such common symbol as ears of wheat that can characterize any raion of Ukraine), and also for the districts which have received the name from the big cities which were not district centers before.

\section{New Chervonohrad Raion}

As an example of the third option, consider the Chervonohrad raion. This district is located in the northern part of the Lviv region, near the border with Poland. It included the territories of the former Sokal and Radekhiv raions, as well as the city of Chervonohrad and the territory of the Chervonohrad City Council (Figure 1).

Since the 12th century, the territory of the present Chervonohrad raion has been a part of Belz principality (Коструба 1989; Козубовський 2014). In the 15th-18th centuries it belonged to the Belz voivodeship. The symbol of this land was the griffin (Гречило 2010, pp. $38,47,48)$. On the images of the 16th century, we can see a crowned silver griffin in a red shield (gules, a griffin rampant argent ducally crowned Or) (Ambrosius 1562; Kamyn 1575, p. 6; Recueil n.d., p. 9) (Figures 2-4). The image of a griffin was one of the most beloved symbols of medieval applied art, which embodied the millennial artistic contacts of the East and the West. For example, the composition of a griffin as a central image is ideally inscribed in the Galician relief slabs in the 12th century (Білик 2017). 


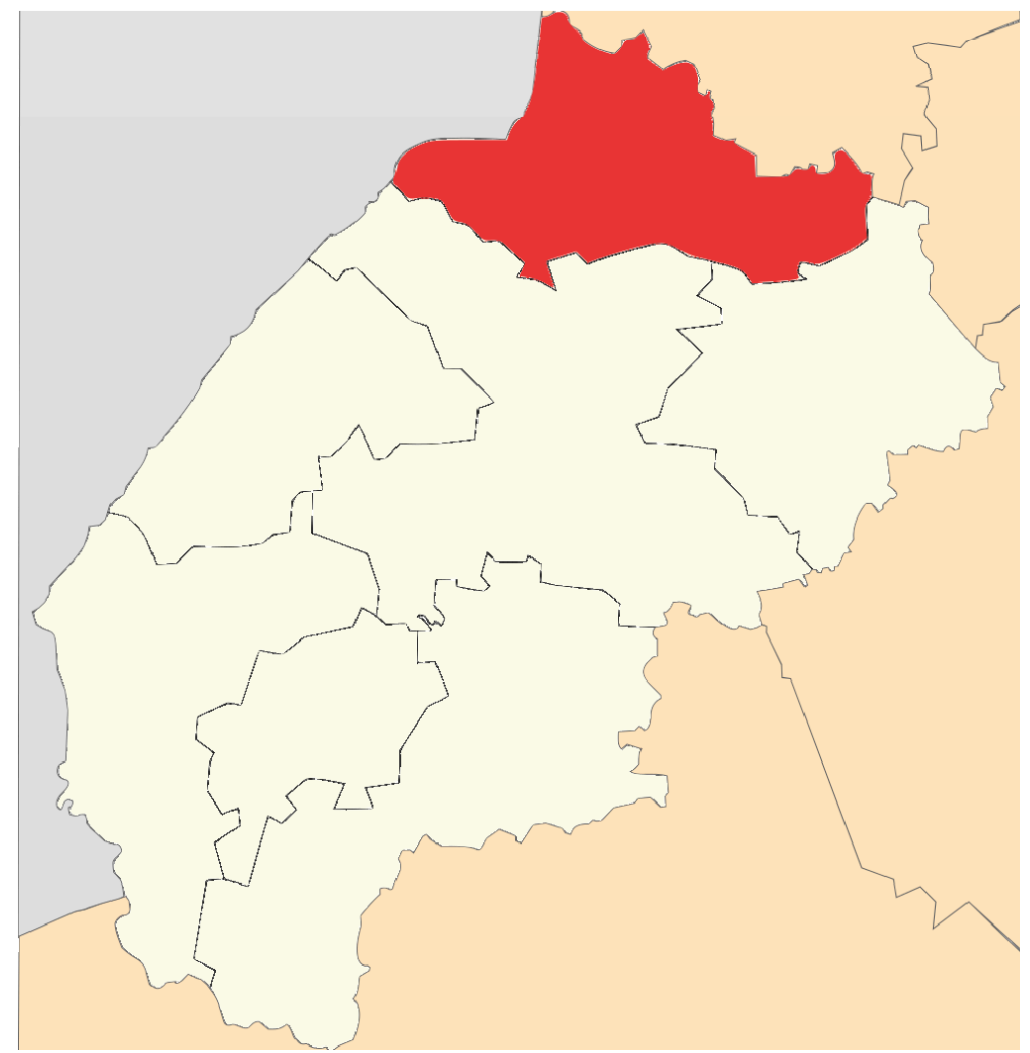

Figure 1. Map of the Chervonohrad rayon in the Lviv oblast.

\section{BELZENSIS TERRA}

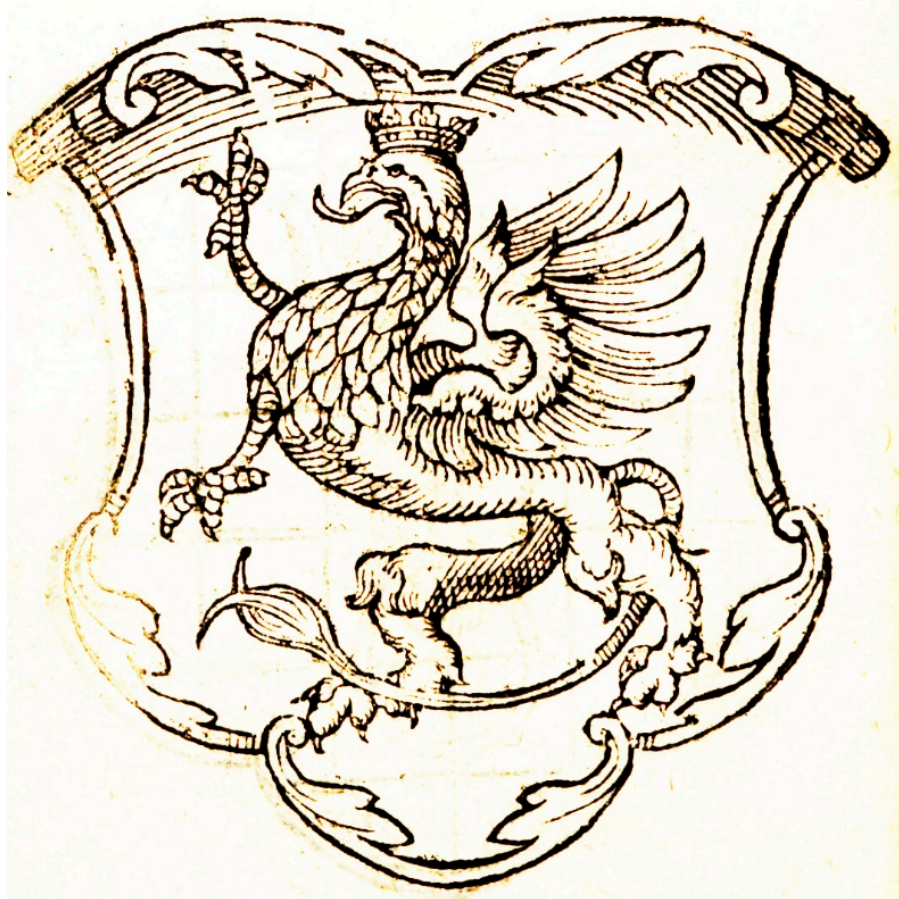

Figure 2. Coat of arms of the Belz land. From: Arma Regni Poloniae, (Ambrosius 1562). 


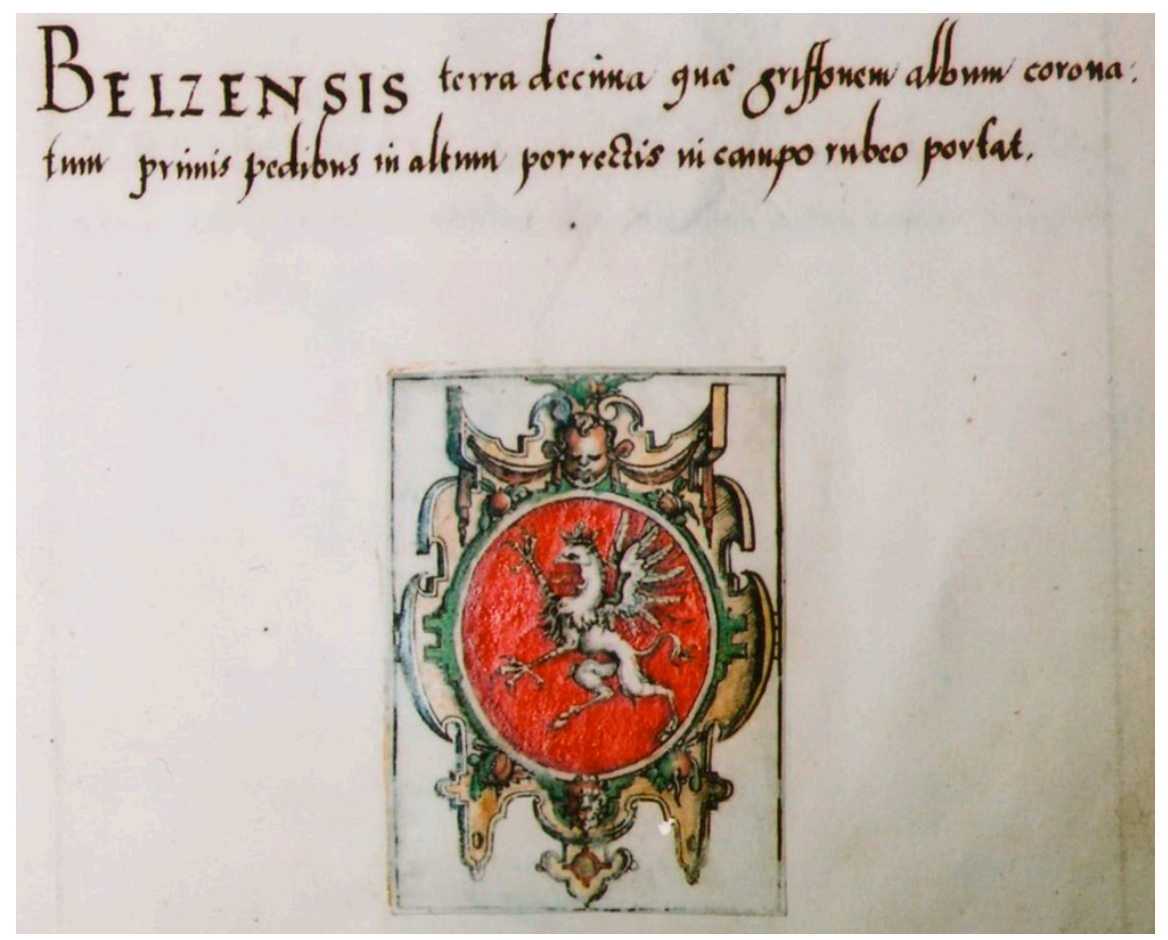

Figure 3. Coat of arms of the Belz land. From: Liber insignorum Regionum atque clenodiorum Regni Poloniae summa cum diligentia elaboratus, (Kamyn 1575, p. 6).

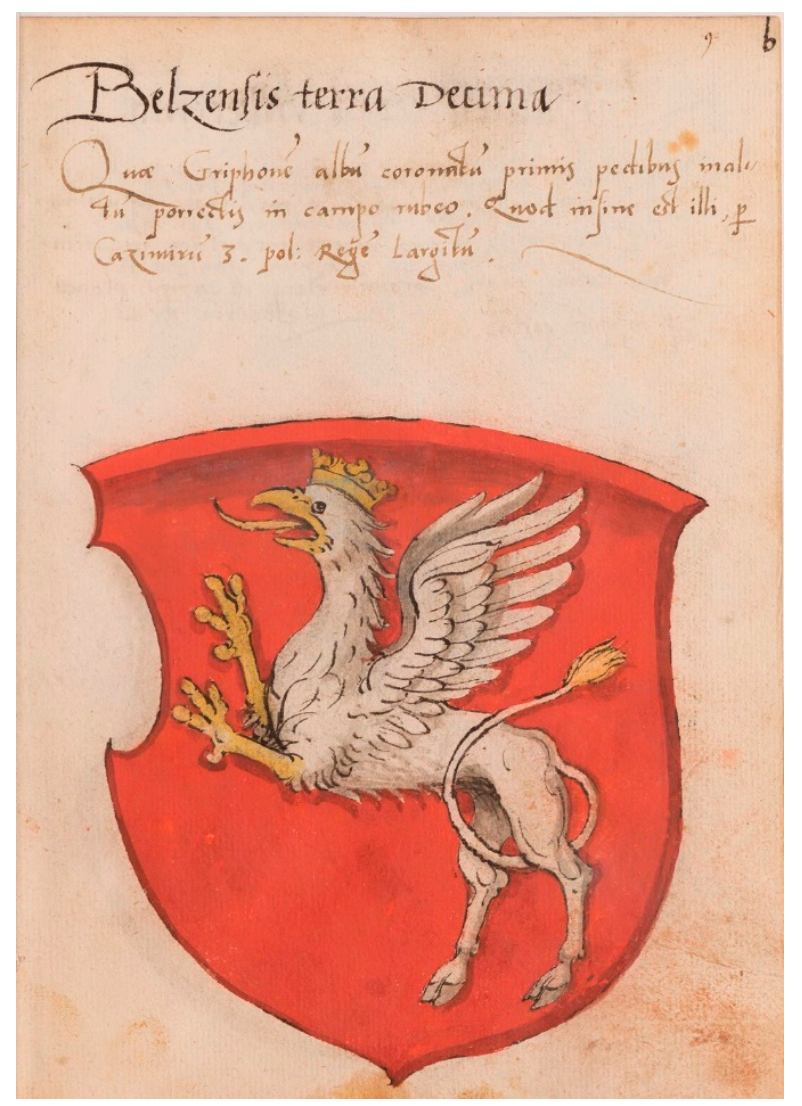

Figure 4. Coat of arms of the Belz land. From: Recueil d'armoiries polonaises. Bibliothèque nationale de France. Bibliothèque de l'Arsenal. Ms-1114, (Recueil n.d., p. 9). 
The city of Chervonohrad has been a significant coal mining industrial center since 1951 (Ясинецька 1992). A village named Novyi Dvir was mentioned at the site in 1525 (Wierzbowski 1912). In 1692, the Crown hetman and Cracow Voivode Feliks Kazimierz Potocki founded a city on the lands of the village and named it "Krystynopol" after his wife Krystyna Lubomirska. Krystynopol passed from Poland to the Ukrainian SSR after the territorial exchange in 1951 and had its name changed to Chervonohrad. Mining motifs were the main features on various unofficial emblems and souvenir badges during the Soviet period (Figure 5). This feature was indicated on the coat of arms of the city, approved in $1976^{2}$ (Figure 6).

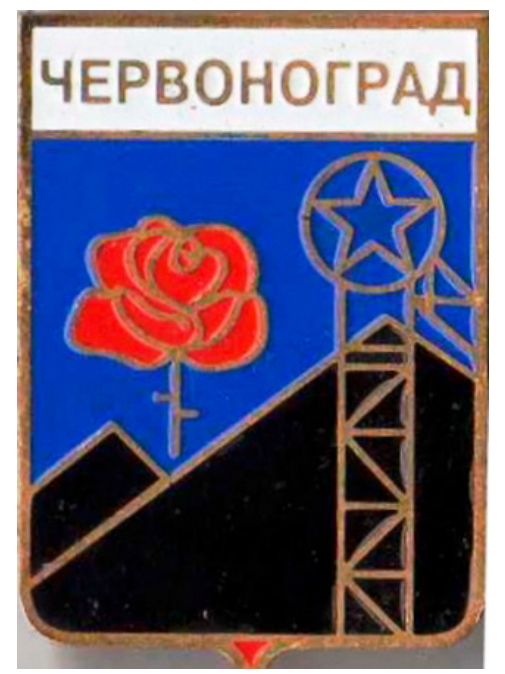

Figure 5. Souvenir badge of Chervonohrad (1980s).

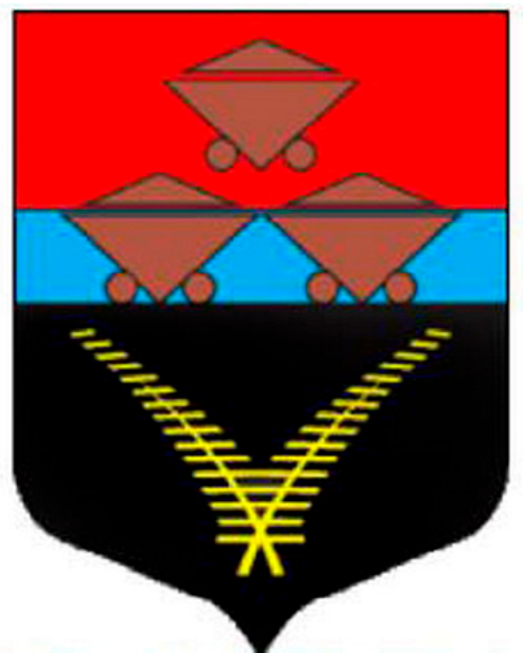

Figure 6. Soviet coat of arms of Chervonohrad (1976).

After the collapse of the Soviet Union and the proclamation of Ukraine's independence, active work began on the creation of municipal and territorial symbols. When the Chervonohrad city council asked Andriy Grechylo in 2002 to develop a new coat of arms of the city, he decided to keep the motif of the symbol from 1976, but change the colors and design (Figures 7 and 8). The new coat of arms of Chervonohrad was approved by the city council on 27 September $2002^{3}$. Red color indicates the name of the city (Ukrainian word "chervonyi" is translated as "red"), and black emphasizes the role of the coal industry in its development (Гречило 2020b, p. 97). The stylized image of golden trolleys with coals and fern branches (which also mean rails) symbolizes wealth and prosperity. 


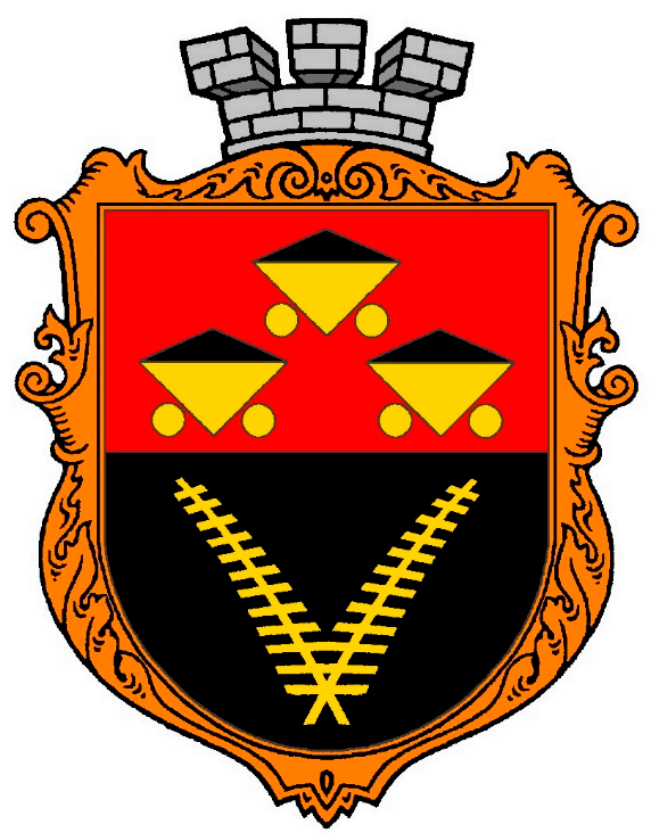

Figure 7. Coat of arms of Chervonohrad (2002).

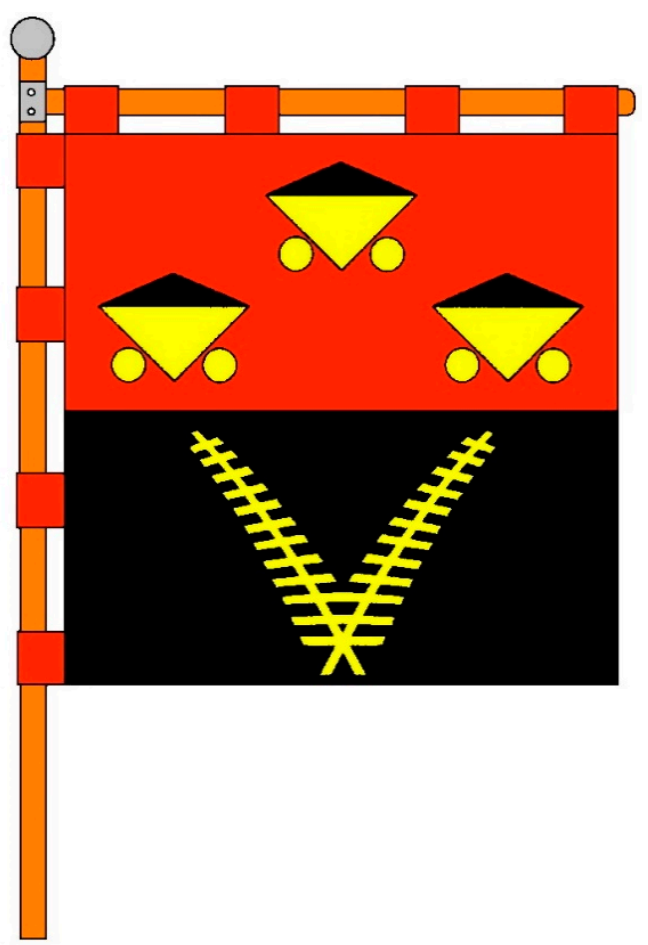

Figure 8. Flag of Chervonohrad (2002).

The symbols of the Sokal raion (designed by Andriy Grechylo) were approved on 16 August $2002^{4}$ (Figures 9 and 10). The falcon indicates the name of the district (Ukrainian word "sokil" is translated as "falcon"), it is also a charge of the coat of arms of Sokal city, but in a different position. The crown symbolizes the ancient Duchy of Belz, as the center of which the city of Belz is located in the contemporary Sokal raion. The falcon on the crown testifies to the region's ancient state traditions and should foster patriotic feelings and pride in its past. In the greater coat of arms, the shield is supported by two silver griffins, which were land symbols of the Belz voivodeship of the 15th-18th centuries. The red and black colors on the flag emphasize the traditions of the struggle of the inhabitants of the Sokal 
region for the freedom of Ukraine. Black also represents the coal industry, which employs many residents of the area.

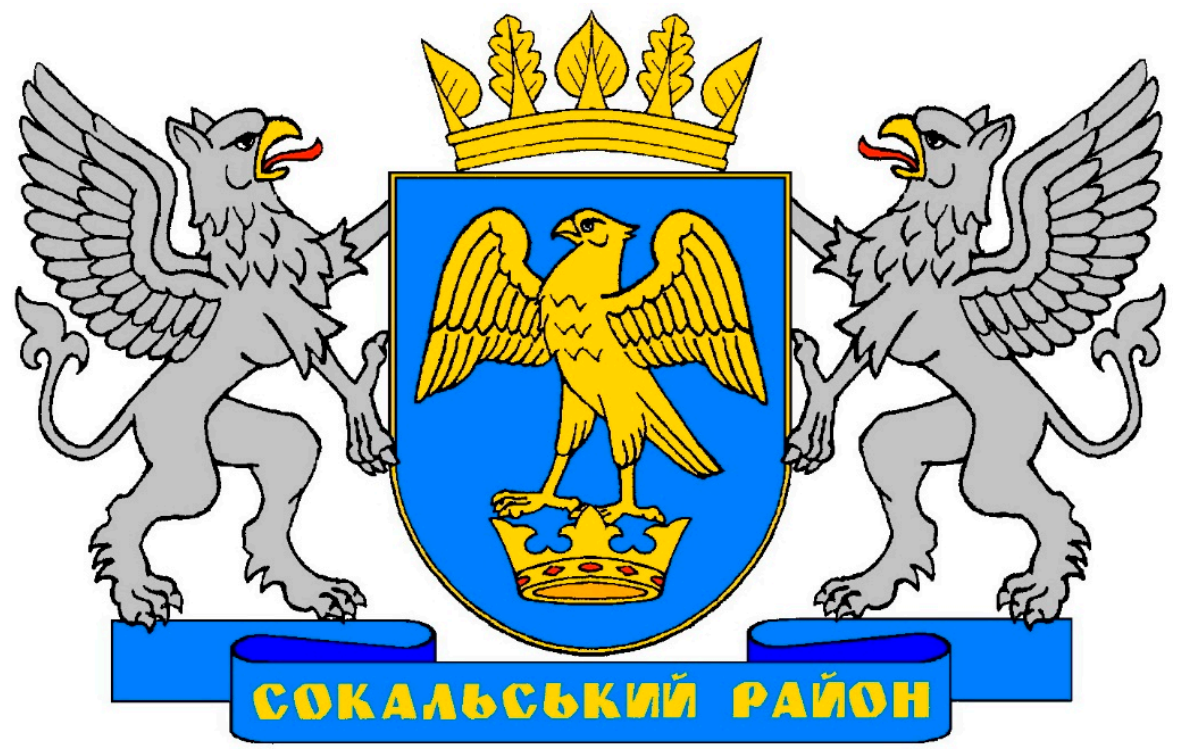

Figure 9. Coat of arms of the Sokal raion (2002).

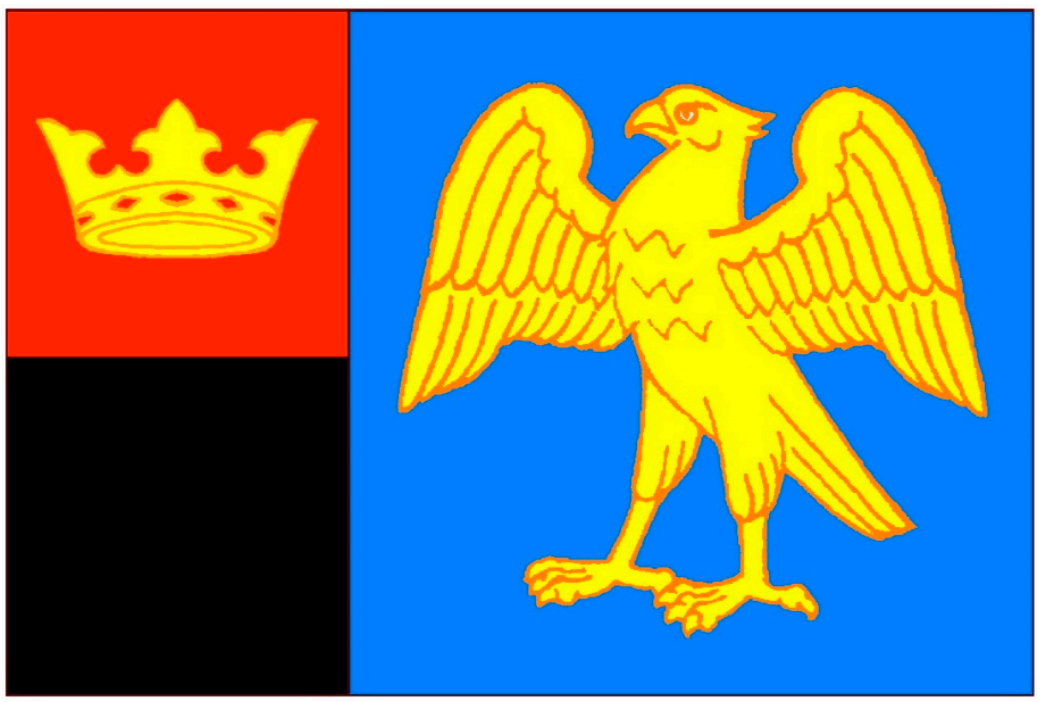

Figure 10. Flag of the Sokal raion (2002).

The author of the symbols of the Radekhiv raion is also Andriy Grechylo. They were approved on 28 October $2003^{5}$ (Figures 11 and 12). The cross indicates the location of the district on the border with the Volyn region. Green means rich forest resources. Red symbolizes the Duchy of Belz. Golden sheaves emphasize the agrarian specialization of the district, and white diamonds mean sugar production. The lion belongs to the Lviv region, and the griffin belongs to the Belz land. 


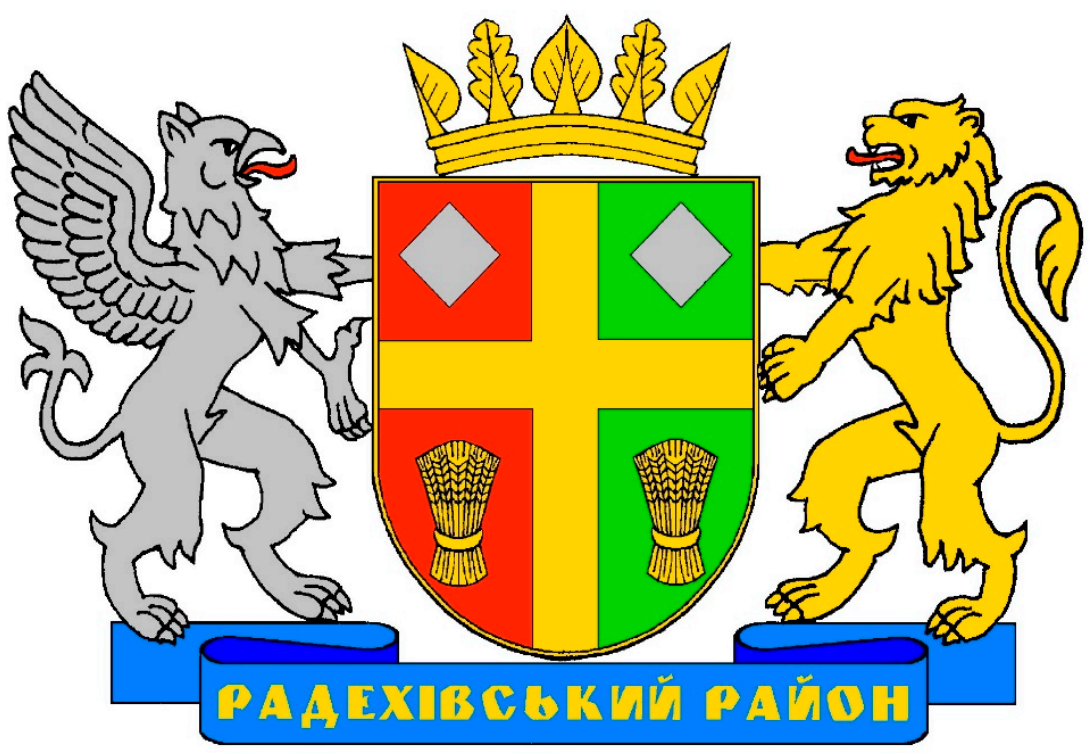

Figure 11. Coat of arms of the Radekhiv raion (2003).

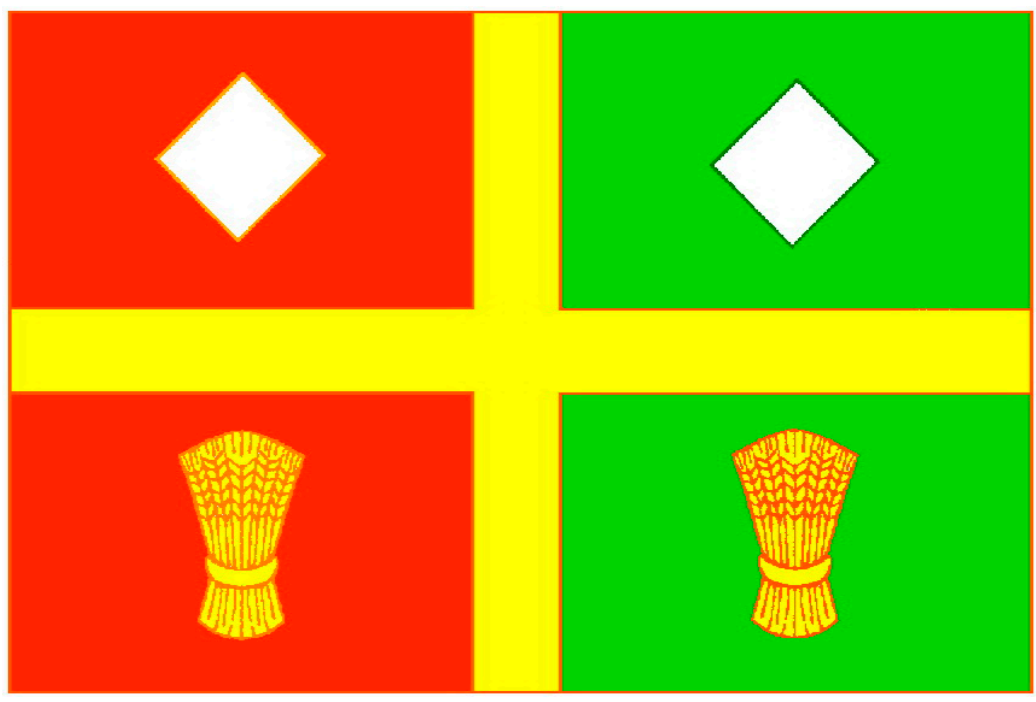

Figure 12. Flag of the Radekhiv raion (2003).

Andriy Grechylo was also approached in June 2021 to design the coat of arms and flag of the new Chervonohrad raion. The new projects managed to combine the symbols of the ancient Belz land, the city of Chervonohrad, and the two old districts (Figures 13-15). The coat of arms and the flag of the Chervonohrad district were approved on 20 August $2021^{6}$.

The coat of arms of the Chervonohrad raion: Per bend sinister gules and sable, a griffin rampant argent langued and beaked Or. The shield ensigned with a district crown (a coronet composed of four oak leaves and four lime leaves) Or. Supporters: On either side, a lion Or, langued gules. Motto: Червоноградський район (Chervonohrad Raion).

The flag of the Chervonohrad raion: A rectangular banner with a width to length ratio of 2:3, divided from the lower corner of the pole diagonally to the upper red and lower black triangular fields, in the center is situated a white griffin with a yellow beak and tongue. 


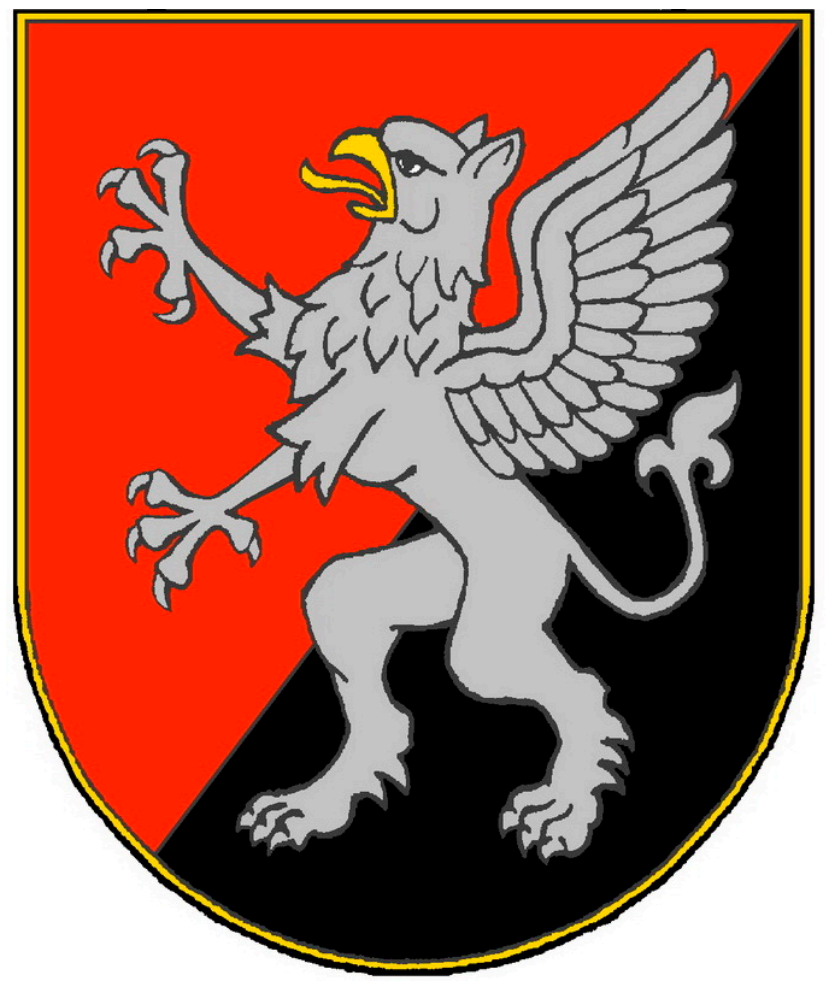

Figure 13. Coat of arms of the Chervonohrad raion (2021).

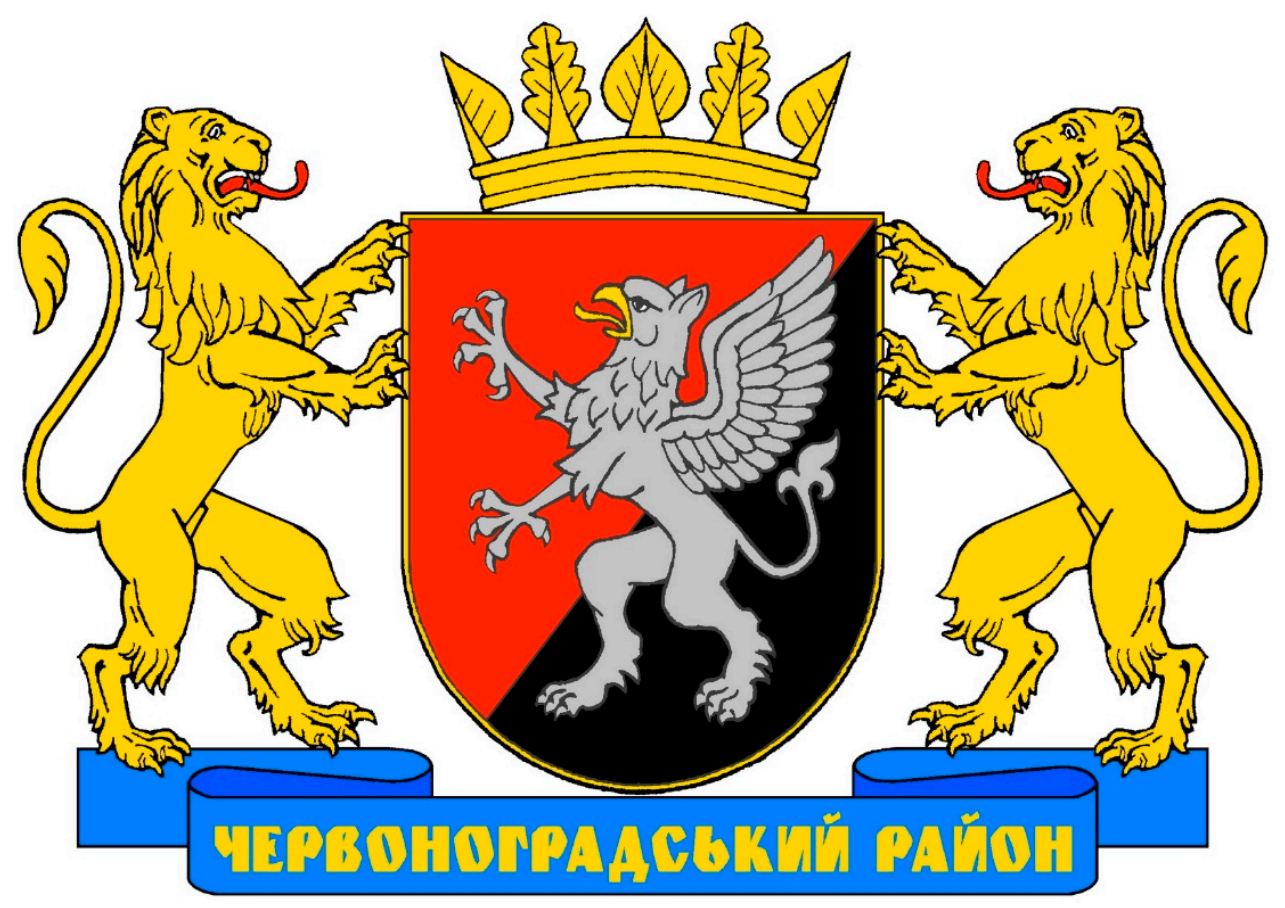

Figure 14. Greater coat of arms of the Chervonohrad raion (2021). 


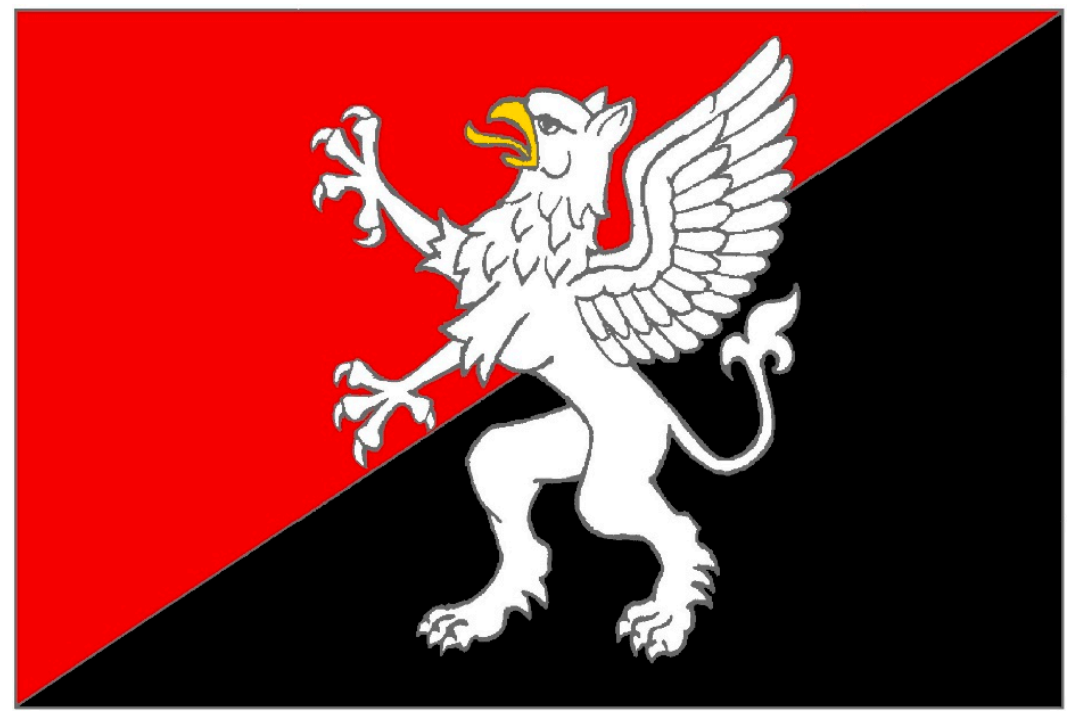

Figure 15. Flag of the Chervonohrad raion (2021).

\section{Conclusions}

The silver griffin is a historical symbol of the Duchy of Belz and the Belz voivodeship, whose territories included the lands of the contemporary Chervonohrad raion. The red color represents the name of the district. Black means fertile lands of Sokal and Radekhiv regions. The combination of red and black symbolizes the city of Chervonohrad and the coal industry, as well as emphasizes the traditions of the national liberation struggle in the region. Lions testify that the district belongs to the Lviv oblast.

The shield can be crowned with a stylized golden territorial crown, which indicates the coat of arms of the district and characterizes its vegetation (crown teeth are solved in the form of tree leaves) - such crowns are already approved in the coats of arms of a number of raion councils. Thus, the symbols of the district reflect the natural features, historical and modern symbols of the region and indicate its administrative status.

The process of organizing and creating symbols for new raions in Ukraine is now accelerating. Several other district councils have sought advice from the Ukrainian Heraldry Society. Let us hope this important project that is meant to capture the character, history, and spirit of the new raions and independent Ukraine will proceed with the appropriate academic rigor.

Funding: This research received no external funding.

Institutional Review Board Statement: No applicable.

Informed Consent Statement: No applicable.

Data Availability Statement: No applicable.

Conflicts of Interest: The author declares no conflict of interest.

\section{Notes}

1 Постанова Верховної Ради України від 17 липня 2020 року No. 807-IX «Про утворення та ліквідацію районів». Decree of the Verkhovna Rada (Parliament) of Ukraine No 807-IX (17 July 2020). Available online: https: / zakon.rada.gov.ua/laws/show / 807-IX\#Text (accessed on 4 December 2021).

2 Рішення IX сесії Червоноградської міської ради депутатів трудящих XV скликання від 26 жовтня 1976. Decision оf the Chervonohrad city council (26 October 1976).

3 Рішення II сесії Червоноградської міської ради IV демократичного скликання від 27 вересня 2002 . No. 42 «Про затвердження герба та прапора міста Червонограда». Decision of the Chervonohrad city council No. 42 (27 September 2002).

4 Рішення III сесії Сокальської районної ради IV скликання від 16 серпня 2002. №. 32 «ро затвердження символіки Сокальського району». Decision of the Sokal raion council No. 32 (16 August 2002). 
Рішення VII сесії Радехівської районної ради IV демократичного скликання від 28 жовтня 2003. о. 90 «Про затвердження символіки Радехівського району». Decision of the Radekhiv raion council No. 90 (28 October 2003).

6 Рішення X сесії Червоноградської районної ради VIII скликання від 20 серпня 2021. No. 113 «Про затвердження символіки Радехівського району Львівської області». Decision of the Chervonohrad raion council No. 133 (20 August 2021).

\section{References}

Ambrosius, Marcus de Nissa. 1562. Arma Regni Poloniae (Coats of arms of the Kingdom of Poland). Antwerp: n.p. (In Latin)

Білик, Олена (Bilyk, Olena). 2017. Образ грифона в галицькому середньовічному мистецтві (The image of the Griffin in Galician medieval art). Мистецтвознавчі записки (Art History Notes) 32: 67-76. (In Ukrainian)

Символіка. 2001. Символіка Броварщини (Symbols of Brovary Raion). Бровари (Brovary): IПPE3 (IPREZ). (In Ukrainian)

Символіка. 2004. Символіка Білоцерківщини (Symbols of Bila Tserkva Raion). Біла Церква (Bila Tserkva): Яніна (Yanina). (In Ukrainian)

Символіка. 2005. Символіка Дрогобиччини (Symbols of Drohobych Raion). Дрогобич (Drohobych): Koло (Kolo). (In Ukrainian)

Гречило, Андрій (Grechylo, Andriy). 2001. Методичні рекомендації з питань геральдики і прапорництва областей, районів, районів у містах та територіальних громад міст, селищ і сіл (територіальні та муніципальні символи) (Меthodical recommendations on heraldry and vexillology of oblasts, raions, raions in cities and territorial communities of cities, settlements and villages (territorial and municipal symbols)). Знак (The Sign) 23: 8-9. (In Ukrainian)

Гречило, Андрій (Grechylo, Andriy). 2010. Українська територіальна геральдика (Ukrainian Territorial Heraldry). Львів (Lviv): Інститут української археографії та джерелознавства ім. М.С. Грушевського НАН України, Українське геральдичне товариство (M.S. Hrushevsky Institute of Ukrainian Archeography and Source Studies, National Academy of Sciences of Ukraine, Ukrainian Heraldry Society). (In Ukrainian)

Гречило, Андрій (Grechylo, Andriy). 2020а. Адміністративно-територіальна реформа і проблеми муніципального та районного герботворення (Administrative-territorial reform and problems of municipal and district emblem formation). Знак (The Sign) 82: 5-6. (In Ukrainian)

Гречило, Андрій (Grechylo, Andriy). 2020b. Герби та прапори міст і сіл Украӥни (Coats-of-arms and Flags of Towns and Villages in Ukraine). Львів (Lviv): Інститут української археографї та джерелознавства ім. М.С.Грушевського НАН України, Українське геральдичне товариство (M.S. Hrushevsky Institute of Ukrainian Archeography and Source Studies, National Academy of Sciences of Ukraine, Ukrainian Heraldry Society). Ч. 2 (Pt. 2). (In Ukrainian)

Kamyn, Erasmus. 1575. Liber Insignorum Regionum Atque Clenodiorum (Regni Poloniae Summa cum Diligentia Elaboratus Book of Coats of Arms of the Lands and Symbols of the Kingdom of Poland). Poznań: n.p. Scientific Library of Ivan Franko National University of Lviv. Ms 995 III. (In Latin)

Коструба, Теофіл (Kostruba, Theophil). 1989. Белз і Белзька земля від найдавніших часів до 1772 року (Belz: The City and the Principality from Ancient Times to 1772). Нью-Йорк and Tоронто (New York and Toronto): Об'єднання надбужанців (The Вuh River Region Association). (In Ukrainian)

Козубовський, Георгій (Kozubovskyi, Heorhiy). 2014. Про Белзьке князівство Юрія Наримунтовича (1352-1377) (Belz principality of Yurii Narymuntovych (1352-1377)). Археологія (Archaeology) 3: 57-66. (In Ukrainian)

Кривенко, Віталій (Kryvenko, Vitaliy), and Костянтин Шляховий (Kostiantyn Shliakhovyi). 2008. Символіка Кіровоградщини (Symbols of the Kirovohrad Oblast). Кіровоград (Kirovohrad): ПВЦ Мавік (PVC Mavik). (In Ukrainian)

Кисляк, Володимир (Kysliak, Volodymyr), ed. 2020. Україна: Герби та прапори (Ukraine: Arms and Flags). Kиїв (Kyiv): Парламентське видавництво (Parliamentary Publishing House). (In Ukrainian)

Recueil. n.d. Recueil d'armoiries polonaises (Collection of Polish Coats of Arms). n.p. Bibliothèque nationale de France, Bibliothèque de l'Arsenal (National Library of France, Library of the Arsenal). Ms-1114. (In Latin)

Терлецький, Юрій (Terletskyi, Yuriy), and Андрій Гречило (Andriy Grechylo). 2006. Сучасна символіка Костопільщини (Сопtemporary Symbols of the Kostopil Raion). Рівне (Rivne): Українське геральдичне товариство (Ukrainian Heraldry Society). (In Ukrainian)

Wierzbowski, Teodor, ed. 1912. Matricularum Regni Poloniae summaria (Summary of the Polish Crown Metrica Books). Warsaw: Officinae C. Kowalewski, pt. 4. vol. 2, p. 316. (No. 14272). (In Latin)

Ясинецька, Оксана (Yasynetska, Oksana). 1992. Новий Двір-Кристинопіль-Червоноград (Novyi Dvir-Krystynopil-Chevonohrad). Львів (Lviv): Kрай (Krai). (In Ukrainian) 